\title{
Effect of Organic Phosphorus on Pre-Harvest and Post-Harvest Traits of Tomato (Lycopersicon Esculentum) Grown Under Field Conditions
}

\author{
Muhammad Yasir ${ }^{1}$, Anum Khalid ${ }^{1}$, Muhammad Musa Khan ${ }^{2 *}$, Muhammad Sajid ${ }^{3 *}$
}

\begin{abstract}
The study was designed to assess the effect of organic phosphorus on the growth, yield and post-harvest fruit traits of tomato. Plants were fertilized with five levels of fertilizers (containing $20 \%$ organic mineralized $\mathrm{P}_{2} \mathrm{O}_{5}, 30 \%$ decomposed organic matter and $2 \%$ organic nitrogen) with the rate of $20,40,60,80$ and $100 \mathrm{~kg} \mathrm{ha}^{-1}$ accompanied with a control. Results showed that Maximum survival percentage, No. of picking/plot, fruit weight, plant height, number of branches, maximum yield was also obtained from the plots treated with $60 \mathrm{~kg} \mathrm{ha}^{-1}$ fertilizer. Plots with $60 \mathrm{~kg} \mathrm{ha}^{-1}$ of organic phosphorus required less days to produce $50 \%$ flowering and $50 \%$ fruit setting. Fruit maturity duration and No. of defective fruits were also minimum in the plots where fertilizer were applied with the rate of $60 \mathrm{~kg} \mathrm{ha}^{-1}$. Results of post-harvest analysis of fruits also revealed that different levels of organic phosphorus (organic phosphorus as a source) have no significant effect on fruit firmness but with the increase in storage time firmness decreases significantly. Total soluble solids were also reduced with the increased level of fertilizer, with the increase in storage time increased the total soluble solids in fruit. Ascorbic acid was found with higher concentrations in high levels of fertilizer which was reduced significantly with the passage of storage time. Fruit juice had maximum $\mathrm{pH}$ value in the control treatment which was significantly reduced with the increase of fertilizer level. However, pH started to increase when fruit was stored for more than 12 days. From the results it can be concluded that fertilization with $60 \mathrm{~kg} \mathrm{ha}^{-}$ ${ }^{1}$, tomato plant can response better during pre-harvest and post-harvest period.
\end{abstract}

Keywords: Ascorbic acid, Fruit firmness, Morphological traits, Shelf life, Total Soluble Solids

\section{INTRODUCTION}

Tomato belongs to family Solanaceae and has originated from the equator to latitude of about $30^{\circ}$, South America. Tomato (Lycopersicon esculentum L.) has got significant importance among vegetable crops and is cultivated widely all over the world both under field and greenhouse conditions (Kimura and Sinha, 2008). In 2011 the total production of tomato in Pakistan was 476.8 thousand tonnes which was grown on almost 50 thousand ha. The average yield in 2011 was about 9.5 t/ha. In 2011 Punjab produced 77.9 (000 tonnes), KPK produced 119.3 (000 tonnes), Sindh 100.4 (000 tonnes) and Balochistan contributed 179.3 (000 tonnes) (Khokhar, 2013). Tomato cultivation is not an easy chore, as the tomato plant is vulnerable to environmental effects (disease, nutrition, climate, insects, pests etc.) and after harvest the fruit has to meet certain market demands (Venema et al., 2008).

Fertilizers application is necessary for better yield of tomato. Many authors have studied the effects of different plant nutrients on growth, quality and yield of tomato and it is proved that some of these nutrients play a vital role in tomato production. For instance, Phosphorus deficient plants have slow development as compared to other plants growing under similar environmental conditions but with sufficient supply of phosphorus (Nutritional recommendations for tomato). Modern cultivars and hybrids of tomato have relatively high growth rates and therefore require an adequate supply of phosphorus for optimal growth and development and high yields. Indeed, as reported by (De Groot et al., 2001), with increasing plant $\mathrm{P}$ concentration the relative growth rate of tomato increases. Recent research results have shown that foliar application of phosphorus in greenhouse tomato enhances the concentrations of chlorophyll, $\mathrm{K}, \mathrm{Mg}$ and $\mathrm{Fe}$ in the leaves, early fruit maturity and increases marketable yield and quality of tomato (Chapagain and Wiesman, 2004). Phosphorus is helpful in root development and also provides energy by formation of ATP (Shaheen et al., 2007). Extending the shelf life of tomatoes is a matter of extreme importance both for domestic and export marketing. Generally tomato fruit shelf life is extended by low temperature storage. More favorable temperature for storage was $130 \mathrm{C}$ as

DOI: 10.21608/ASEJAIQJSAE.2019.52548

${ }^{1}$ Key Laboratory of Horticultural Plant Biology, Ministry of Education, College of Horticulture and Forestry Sciences,

Huazhong Agricultural University, Wuhan, China.

${ }^{2}$ Hubei Insect Resources Utilization and Sustainable Pest Management

Key Laboratory, College of Plant Science and Technology,

Huazhong Agricultural University, Wuhan 430070, China.

${ }^{3}$ Department of Horticulture, Faculty of Crop Production Sciences,

University of Agriculture Peshawar, Khyber Pakhtunkhwa Pakistan.

${ }^{\dagger}$ Authors contributed equally

*Corresponding Author: Muhammad Sajid msajid@aup.edu.pk

Muhammad Musa Khan drmusakhan@outlook.com

Received July 13, 2019, Accepted September 28, 2019 
compared to $24 \mathrm{OC}$ for prolonged shelf life and increasing vitamin $\mathrm{C}$ content of fruits (Corbo et al., 2004). The $\mathrm{pH}$ of the fruit increases throughout development (Thumula, 2006). Phosphorus has a positive effect on fruit acid and sugar content (Dabire et al., 2016).

\section{MATERIALS AND METHODS}

The seeds of tomato were sown in February and transplanted to field in March. The seed beds were made $10 \mathrm{~cm}$ raised from the surface to avoid over irrigation. The experimental plots were ploughed three times before transplantation. The used plot size was $2 \mathrm{~m} \times 2 \mathrm{~m}$ (Plot area $=4 \mathrm{~m}^{2}$ ). There were two rows in each plot, containing 6 plants row $^{-1}$, in which plant to plant distance was maintained at $30 \mathrm{~cm}$ while row to row distance was at $75 \mathrm{~cm}$. Phosphorus (organic phosphorus as a source) was applied once after 15 days of transplanting. Bio Organo Phosphate (BOP) a patent product of Niha Corporation which is a modern BioTech solution provider was used as an organic source of phosphorus. The composted organic material, coated with carbon rich material for longer sustainability of microbes was used as phosphorus source. BOP contain $20 \%$ organic mineralized $\mathrm{P}_{2} \mathrm{O}_{5}, 30 \%$ decomposed organic matter and $2 \%$ organic nitrogen. Organic Phosphorus $(0,20,40,60,80$ and $100 \mathrm{~kg}$ ha-1) with above mentioned composition was applied to tomato plants. The used experimental design was Randomized Complete Block Design. The data was recorded on following parameters:

\section{Survival percentage}

Number of plants survived out of total transplanted was counted and then the \% age was calculated according to the following formula:

\section{Survival Percentage$$
=\frac{\text { Number of plants sruvived }}{\text { Total number of plant transplanted }} \times 100
$$

\section{Days to $50 \%$ flowering}

The data was recorded by randomly selecting six plants in each plot of every replication and days to $50 \%$ flowering was recorded when flowers appeared on three out of six plants from the date of transplanting.

\section{Days to $50 \%$ fruit set}

Six plants were randomly selected in each plot of every replication and data was recorded when $50 \%$ flowers appeared plants from the date of transplanting.

\section{Plant height (cm)}

The data on plant height $(\mathrm{cm})$ was recorded for six randomly plants in each plot of every replication.
The height was measured from the ground to tip of the plant.

\section{Yield (Kg ha-1)}

Yield $\mathrm{ha}^{-1}$ was calculated using the following formulae.

Yield per ha $=\frac{\text { Yield per plot }(\mathrm{Kg}) \times 10000 \mathrm{Sq} . \mathrm{m}}{\text { Plot area }(\mathrm{Sq} . \mathrm{m})}$

\section{Fruit firmness (Kg cm-2)}

Penetrometer (model FT $011\left(0-11 \mathrm{~kg} \mathrm{~cm}^{-2}\right)$ was used to measure the fruit firmness of the selected fruits. After holding the fruit firmly in one hand, a small layer of the skin was detached from it. Then by using the two fingers and palm of the other hand tightly held the penetrometer. Now pushed the penetrometer into the peeled portion until the knob touched the surface of fruit. Then reading was noted and their means were calculated.

\section{Total soluble solids ( ${ }^{\circ}$ Brix)}

Hand refractometer was used to observe the total soluble solids of the selected fruits from every treatment. Put 1 or 2 drops of sample on the dry surface of prism of refractometer and then reading was noted. In order to get exact results for each reading, distilled water was used to wash the prism and then cleaned with tissue paper.

\section{Fruit juice $\mathbf{p H}$}

pH meter (Model no. INOLAB pH-720) was used to measure the fruit juice $\mathrm{pH}$ for all the treatments of the selected tomato fruits. Before using the $\mathrm{pH}$ meter, standardized it with standard buffer solution to adjust the $\mathrm{pH}$ of electrodes to neutral. Juice of the fruits was extracted by using juicer. The recommended amount of sample of juice was collected in a beaker and dipped the electrodes of $\mathrm{pH}$ meter in it for few minutes. Temperature dial was already set to $\mathrm{pH}$ meter, then noted the $\mathrm{pH}$ reading carefully.

\section{Ascorbic acid content (mg 100g-1)}

Ascorbic acid content of tomato fruit juice was determined by using the standard method as explained in AOAC (2000). Dye solution was prepared by taking 2, 6 Dichloroindophenole dye $(50 \mathrm{mg})$ and sodium bicarbonate $\left(\mathrm{NaHCO}_{3}\right)(42 \mathrm{mg})$ in $200 \mathrm{ml}$ beaker and dissolved them properly by adding hot distilled water in to it, then stirred the beaker for 30 minutes and made the volume in a volumetric flask up to $250 \mathrm{ml}$. To prepare the oxalic acid solution, oxalic acid (0.4 g) was taken and mixed in distilled water, shaken it properly until all the oxalic acid dissolved properly in distilled water and then $100 \mathrm{ml}$ volume was prepared. For the preparation of standard solution of ascorbic acid, 
dissolve $50 \mathrm{mg}$ of the ascorbic acid in $50 \mathrm{ml}$ of the $0.4 \%$ oxalic acid solution. Then $2 \mathrm{ml}$ of this solution was taken into a conical flask. After that titrated the solution against dye solution until pink color appeared after 15 seconds. The following formula was used to calculate the dye factor.

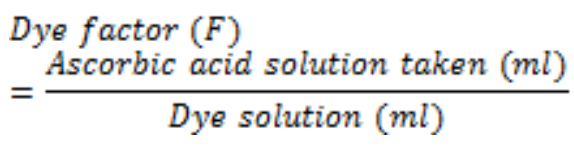

Oxalic acid solution $(0.4 \%)$ was taken and diluted the $1 \mathrm{ml}$ sample of tomato fruit juice to adjust the volume of $10 \mathrm{ml}$. Then, titration of the $10 \mathrm{ml}$ distilled sample against the standard dye solution was done until light pink color appeared that remained for 15 seconds. Following formula was used to calculate ascorbic acid content:

$$
\begin{array}{r}
\text { Ascorbic acid content }(\mathrm{mg} \text { per } 100 \mathrm{~g}) \\
=\frac{T \times F \times 100 \times 100}{S \times D}
\end{array}
$$

$\mathrm{T}=$ dye solution used $(\mathrm{ml}), \mathrm{F}=$ standardization factor, $\mathrm{D}=$ diluted sample for titration $(\mathrm{ml})$ and $\mathrm{S}=$ tomato juice for dilution $(\mathrm{g})$

\section{Statistical Analysis}

Filed parameters e.g. percent survival, The data recorded was subjected to Analysis of Variance technique appropriate for Completely Randomized Design with two factors factorial arrangement and Randomized Complete Block Design with one factor factorial arrangement. Means were compared by using Least Significance Difference (LSD) test when $P$ values were significant. Statistical software (Statistics 8.1) was used for calculating analysis of variance and LSD.

\section{RESULTS}

1. Pre Harvest effects of organic phosphorus on different plant traits

\subsection{Survival percentage}

The mean data (Fig. 1A) showed that survival percentage had increased significantly by phosphorus application. The maximum survival percentage $(83.13 \%)$ was recorded in plants getting phosphorus at the rate of $60 \mathrm{~kg} \mathrm{ha}^{-1}$ followed by plants $(77.63 \%)$ treated with phosphorus $40 \mathrm{~kg} \mathrm{ha}^{-1}$. While less number of plants survived $(70.09 \%)$ in control treatment.

\subsection{Days to $50 \%$ flowering}

The data regarding days to $50 \%$ flowering (Fig. 1B) of tomato plant revealed a positive significant effect of phosphorus. Early flowering (30.33) was observed in plants treated with $60 \mathrm{~kg} \mathrm{ha}^{-1}$ phosphorus followed by plants fertilized at $40 \mathrm{~kg} \mathrm{ha}^{-1}$ (33.70), $80 \mathrm{~kg} \mathrm{ha}^{-1}$ (35.20), $100 \mathrm{~kg} \mathrm{ha}^{-1}$ (40.10), and $20 \mathrm{~kg} \mathrm{ha}^{-1}$ (37.83) respectively. More days to flowering (43.52) were observed in control treatment. Phosphorus has a vital role in development of reproductive parts of the plants. So the number of days to $50 \%$ flowering might be of the reason that phosphorus enhances the flower production of tomato plants.

\subsection{Days to $50 \%$ fruiting}

The findings related to days to 50\% fruiting (Fig 1C) of tomato plant showed a positive significant effect of organic phosphorus. Early fruiting (42.28) was given by plants treated with $60 \mathrm{~kg} \mathrm{ha}^{-1}$ phosphorus followed by plants fertilized at $40 \mathrm{~kg} \mathrm{ha}^{-1}$ (46.09), 80 $\mathrm{kg} \mathrm{ha}^{-1}$ (48.37), $100 \mathrm{~kg} \mathrm{ha}^{-1}$ (51.51) and $20 \mathrm{~kg} \mathrm{ha}^{-1}$ (50.23) respectively. More days to fruiting (53.01) were observed in control treatment. Due to early flowering by phosphorus application might be a good reason to have early fruiting.

\subsection{Days to fruit maturity}

The result (Fig. 1D) indicated that fewer days to fruit maturity (65.00) was recorded in the plants applied with $60 \mathrm{~kg}$ ha-1 phosphorus following the plants fertilized at $40 \mathrm{~kg}$ ha-1 (68.91), $80 \mathrm{~kg}$ ha-1 (70.67), $100 \mathrm{~kg}$ ha-1 (75.42), and $20 \mathrm{~kg}$ ha-1 (73.63) respectively. More days to fruit maturity (78.30) were observed in control treatment. Fruit maturity is critical part of tomato plant.

\subsection{Number of pickings plot $^{-1}$}

The results (Fig. 1E) indicated that no of pickings plot-1 was prominently affected by phosphorus application. The more number of pickings plot-1 (6.16) was recorded in plants applied with $60 \mathrm{~kg}$ ha1 phosphorus following the plants fertilized at $40 \mathrm{~kg}$ ha-1 (5 .60) which was at par to $80 \mathrm{~kg}$ ha-1 phosphorus. The least number of pickings plot-1 (4.05) was noted in plants not applied with phosphorus. The increased no of pickings plot-1 might have the reason that phosphorus helped in reproductive growth of plant which ultimately increased number of fruits plant-1.

\subsection{Average fruit weight (g)}

Results (Fig. 1F) reveled that phosphorus has a positive significant affect on the average fruit weight of tomato. Bigger fruit $(65.58 \mathrm{~g})$ was obtained from 

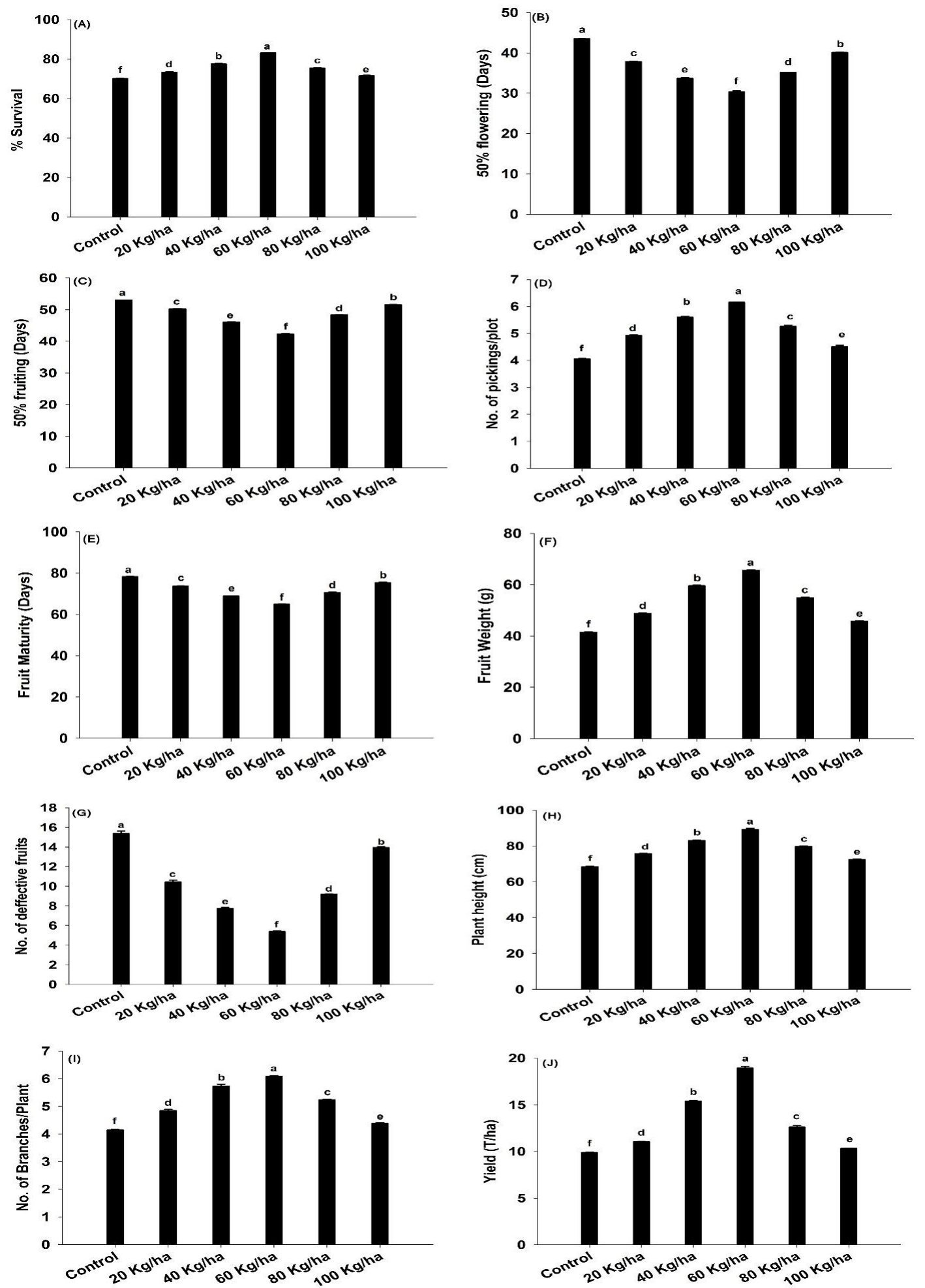

Fig. 1. Effect of different phosphorus levels $(0 \mathrm{Kg} / \mathrm{ha}, 20 \mathrm{Kg} / \mathrm{ha}, 40 \mathrm{~kg} / \mathrm{ha}, 60 \mathrm{Kg} / \mathrm{ha}, 80 \mathrm{Kg} / \mathrm{ha}$ and $100 \mathrm{Kg} / \mathrm{ha})$ on different quantitative parameters of tomato before harvesting. Bar are showing mean values of 3 replications. Lettering on bars showing the significance among the treatments. Similar letters showing non-significance of the treatments. Significance level was adjusted on $P<0.05$ 
plants fertilized with phosphorus $60 \mathrm{~kg}$ ha- 1 , followed by $(59.55 \mathrm{~g})$ at $40 \mathrm{~kg}$ ha-1 phosphorus. While the lowest fruit weight $(41.39 \mathrm{~g})$ was obtained from unfertilized plants.

\subsection{Percent defective fruits $(\%)$}

The results (Fig. 1G) indicated that phosphorus had a positive significant effect on percent defective fruits. More defective fruits $(15.38 \%)$ were recorded in control plants followed by plants fertilized at $100 \mathrm{~kg}$ ha-1 (13.96\%), $20 \mathrm{~kg}$ ha-1 $(10.44 \%), 80 \mathrm{~kg}$ ha-1 $(9.19 \%)$ and $40 \mathrm{~kg}$ ha-1 (7.72\%) respectively. Least defective fruits $(5.39 \%)$ were recorded in plants treated with $60 \mathrm{~kg}$ ha-1 phosphorus.

\subsection{Plant height (cm)}

The mean values of plant height (Fig. 1H) showed that organic phosphorus had a positive significant effect on plant height of tomato plant. The maximum plant height $(89.29 \mathrm{~cm})$ was recorded in plants that received phosphorus at $60 \mathrm{~kg} \mathrm{ha}^{-1}$ followed by plant height $(83.12 \mathrm{~cm})$ treated with phosphorus at $40 \mathrm{~kg}$ $\mathrm{ha}^{-1}$. The plant height $(79.85,72.56$ and $75.69 \mathrm{~cm})$ was recorded for phosphorus levels 80, 100 and 20 $\mathrm{kg} \mathrm{ha}^{-1}$ respectively. While minimum plant height $(63.42 \mathrm{~cm})$ was recorded in control treatment.

\subsection{Number of branches plant ${ }^{-1}$}

The means showed (Fig. 1I) that more number of branches (6.09) was observed in plants fertilized with phosphorus at $60 \mathrm{~kg}$ ha-1, followed by (5.74) branches plant-1 treated with phosphorus $40 \mathrm{~kg}$ ha- 1 . Minimum number of branches (4.14) was recorded for plants receiving no phosphorus which was statistically at par with 20 and $100 \mathrm{~kg}$ ha-1 phosphorus.

\subsection{Yield (ton ha-1)}

The data regarding days to $50 \%$ flowering (Fig. 1J) of tomato plant revealed a positive significant effect of phosphorus. The maximum yield (18.95 ton ha-1) was given by plants treated with $60 \mathrm{~kg}$ ha-1 phosphorus followed by plants fertilized at $40 \mathrm{~kg}$ ha1 (15.42 ton ha-1), $80 \mathrm{~kg}$ ha-1 (12.63 ton ha-1), 20 kg ha-1 (11.07 ton ha-1) and $100 \mathrm{~kg}$ ha-1 (10.35 ton ha-1) respectively.

\section{Post-harvest fruit quality assessment}

\subsection{Fruit Firmness $\left(\mathrm{kg} \mathrm{cm}^{-2}\right)$}

Results (Table 1) showed that different levels of phosphorus showed non-significant effects on the firmness of the fruit $(\mathrm{F}=0.50, \mathrm{P}=0.77)$. Storage conditions played a significant role in the firmness of the fruit $(\mathrm{F}=371.95, \mathrm{P}=0.00)$. Results showed that as the storage time increases the firmness of the fruit decreases. Maximum firmness was recorded at Oday of storage $1.35 \mathrm{~kg} \mathrm{~cm}-2$ which was recorded at it most minimum value of $0.78 \mathrm{~kg} \mathrm{~cm}-2$ after 12 days of storage.

\subsection{Total soluble solids ( ${ }^{\circ}$ Brix)}

The results (Table 1) clearly indicated that different phosphorus levels $\left(20,40,60,80\right.$ and $\left.100 \mathrm{~kg} \mathrm{ha}^{-1}\right)$ had a positive significant effect on the total soluble solids ( ${ }^{\circ}$ Brix) of the tomato fruits $(\mathrm{F}=1485.66$, $\mathrm{P}=0.00)$. Highest total soluble solids of tomato fruit (4.24 ${ }^{\circ}$ Brix) was observed in control which started to be decreases as the level of phosphorus increases 3.07 ${ }^{\circ}$ Brix was recorded in the plot where phosphorus was applied with the rate of $100 \mathrm{~kg}$ ha- 1 . Storage duration also showed significant influence on total soluble solids ( $\mathrm{F}=567.28, \mathrm{P}=0.00)$. Results showed that minimum TTS $\left(3.80{ }^{\circ}\right.$ Brix $)$ was recorded at 0days of storage and maximum TTS was recorded after 12 days of storage $\left(4.17{ }^{\circ}\right.$ Brix) which revealed TTS in fruit increases as the storage duration increases.

\subsection{Ascorbic acid (mg $\left.100 \mathrm{~g}^{-1}\right)$}

The results (Table 1) showed that increasing phosphorus rates of application had a positive significant on the ascorbic acid content in the juice of tomato fruits. As the levels of phosphorus increased, the ascorbic acid content of fruit increased $(\mathrm{F}=1423.55, \mathrm{P}=0.00)$. Maximum ascorbic acid (3.85 mg 100g-1) was recorded in plants that received phosphorus at $100 \mathrm{~kg}$ ha-1 followed by ascorbic acid content $(3.78 \mathrm{mg} \mathrm{100g-1)}$ observed by the fruits of the plants treated with $80 \mathrm{~kg}$ ha-1. Minimum ascorbic acid content (3.58 mg 100g-1) was observed in fruits of untreated plants. The ascorbic acid of tomato fruit significantly $(\mathrm{F}=562.71$, $\mathrm{P}=0.00)$ reduced during the storage conditions. The highest ascorbic acid content (3.79 mg 100g-1) was observed in freshly harvested fruits, following (3.75 mg 100g-1) in fruits that was stored for 03 days respectively, however the least ascorbic acid content (3.59 mg 100g-1) was recorded in tomato fruit that was stored for 12days.

\section{Post-harvest fruit quality assessment}

\subsection{Fruit Firmness $\left(\mathrm{kg} \mathrm{cm}^{-2}\right)$}

Results (Table 1) showed that different levels of phosphorus showed non-significant effects on the firmness of the fruit $(\mathrm{F}=0.50, \mathrm{P}=0.77)$. Storage conditions played a significant role in the firmness of the fruit $(\mathrm{F}=371.95, \mathrm{P}=0.00)$. Results showed that as the storage time increases the firmness of the fruit decreases. 
Table 1. Effect of phosphorus on different qualitative parameters

\begin{tabular}{|c|c|c|c|c|c|}
\hline Treatment & $\begin{array}{c}\text { Treatment } \\
\text { levels }\end{array}$ & $\begin{array}{c}\text { Firmness } \\
\left(\mathrm{kg} \mathrm{cm}^{-2}\right)\end{array}$ & TSS $\left({ }^{\circ}\right.$ Brix $)$ & $\begin{array}{c}\text { Ascorbic acid } \\
\left(\mathrm{mg} \mathrm{100g}^{-1}\right)\end{array}$ & pH \\
\hline \multirow{8}{*}{ 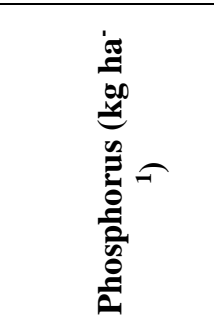 } & 0 & $1.14 \mathrm{a}$ & $4.24 a$ & $3.58 \mathrm{f}$ & $3.71 \mathrm{a}$ \\
\hline & 20 & $1.13 \mathrm{a}$ & $4.02 \mathrm{~b}$ & $3.61 \mathrm{e}$ & $3.41 \mathrm{~b}$ \\
\hline & 40 & $1.13 \mathrm{a}$ & $3.95 \mathrm{c}$ & $3.66 \mathrm{~d}$ & $3.34 \mathrm{c}$ \\
\hline & 60 & $1.12 \mathrm{a}$ & $3.83 \mathrm{~d}$ & $3.73 c$ & $3.28 \mathrm{~d}$ \\
\hline & 80 & $1.15 \mathrm{a}$ & $3.79 \mathrm{e}$ & $3.78 b$ & $3.23 \mathrm{e}$ \\
\hline & 100 & $1.13 \mathrm{a}$ & $3.70 \mathrm{f}$ & $3.85 \mathrm{a}$ & $3.17 \mathrm{f}$ \\
\hline & $F$-value & 0.50 & 1485.66 & 1423.55 & 1198.23 \\
\hline & $P$-value & 0.77 & 0.00 & 0.00 & 0.00 \\
\hline \multirow{7}{*}{ 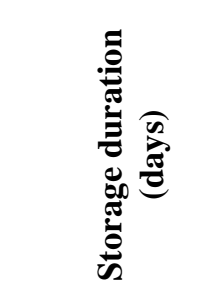 } & 0 & $1.35 \mathrm{a}$ & $3.80 \mathrm{e}$ & $3.79 \mathrm{a}$ & $3.23 \mathrm{e}$ \\
\hline & 3 & $1.29 b$ & $3.85 \mathrm{~d}$ & $3.75 b$ & $3.28 \mathrm{~d}$ \\
\hline & 6 & $1.21 \mathrm{c}$ & $3.90 \mathrm{c}$ & $3.71 \mathrm{c}$ & $3.34 \mathrm{c}$ \\
\hline & 9 & $1.07 \mathrm{~d}$ & $3.98 \mathrm{~b}$ & $3.64 \mathrm{~d}$ & $3.43 b$ \\
\hline & 12 & $0.78 \mathrm{e}$ & $4.07 \mathrm{a}$ & $3.59 \mathrm{e}$ & $3.50 \mathrm{a}$ \\
\hline & $F$-value & 371.95 & 567.28 & 562.71 & 496.23 \\
\hline & P-value & 0.00 & 0.00 & 0.00 & 0.00 \\
\hline Interaction & $\mathrm{S} \times \mathrm{P}$ & NS & $*$ & $*$ & $*$ \\
\hline
\end{tabular}

Mean values of fruit firmness, total soluble solids, Ascorbic acid and $\mathrm{pH}$ of fruit juice of tomato computed from three replications on the basis of Phosphorus level and storage duration. The lettering showing the significance of treatments at $\mathrm{P}<0.05$. NS is nonsignificant and Asterisk showing the significance of the interaction of S (Storage duration) and P (Level of Phosphorus).

Maximum firmness was recorded at 0day of storage $1.35 \mathrm{~kg} \mathrm{~cm}-2$ which was recorded at it most minimum value of $0.78 \mathrm{~kg} \mathrm{~cm}-2$ after 12 days of storage.

\subsection{Total soluble solids ( ${ }^{\circ}$ Brix)}

The results (Table 1) clearly indicated that different phosphorus levels $\left(20,40,60,80\right.$ and $\left.100 \mathrm{~kg} \mathrm{ha}^{-1}\right)$ had a positive significant effect on the total soluble solids ( ${ }^{\circ}$ Brix) of the tomato fruits $(\mathrm{F}=1485.66$, $\mathrm{P}=0.00$ ). Highest total soluble solids of tomato fruit $\left(4.24{ }^{\circ}\right.$ Brix) was observed in control which started to be decreases as the level of phosphorus increases $3.07{ }^{\circ}$ Brix was recorded in the plot where phosphorus was applied with the rate of $100 \mathrm{~kg}$ ha- 1 . Storage duration also showed significant influence on total soluble solids $(\mathrm{F}=567.28, \mathrm{P}=0.00)$. Results showed that minimum TTS $\left(3.80{ }^{\circ}\right.$ Brix $)$ was recorded at Odays of storage and maximum TTS was recorded after 12 days of storage $\left(4.17{ }^{\circ}\right.$ Brix $)$ which revealed TTS in fruit increases as the storage duration increases.

\subsection{Ascorbic acid (mg $\left.100 \mathrm{~g}^{-1}\right)$}

The results (Table 1) showed that increasing phosphorus rates of application had a positive significant on the ascorbic acid content in the juice of tomato fruits. As the levels of phosphorus increased, the ascorbic acid content of fruit increased $(\mathrm{F}=1423.55, \mathrm{P}=0.00)$. Maximum ascorbic acid (3.85 mg 100g-1) was recorded in plants that received phosphorus at $100 \mathrm{~kg}$ ha- 1 followed by ascorbic acid content (3.78 mg 100g-1) observed by the fruits of the plants treated with $80 \mathrm{~kg}$ ha- 1 . Minimum ascorbic acid content (3.58 mg 100g-1) was observed in fruits of untreated plants. The ascorbic acid of tomato fruit significantly $(\mathrm{F}=$ 562.71, $\mathrm{P}=0.00$ ) reduced during the storage conditions. The highest ascorbic acid content (3.79 mg 100g-1) was observed in freshly harvested fruits, following (3.75 mg 100g-1) in fruits that was stored for 03 days respectively, however the least ascorbic acid content (3.59 mg 100g-1) was recorded in tomato fruit that was stored for 12days.

\subsection{Fruit juice pH}

The results in (Table 1) showed a positive significant effect on fruit juice $\mathrm{pH}$ of tomato fruits by increased phosphorus application. The highest fruit juice $\mathrm{pH}$ (3.71) was recorded in untreated plants while, least fruit juice $\mathrm{pH}$ (3.17) was recorded by the plants treated with $100 \mathrm{~kg}$ ha-1 phosphorus $(\mathrm{F}=1198.23$, $\mathrm{P}=0.00$ ). The fruit juice $\mathrm{pH}$ increased as storage days increased. The maximum fruit juice $\mathrm{pH}$ (3.50) was recorded in fruits that were stored at 12 days, following (3.43) in those fruits stored for 9 days $(\mathrm{F}=496.83, \mathrm{P}=0.00)$. While, the least fruit juice $\mathrm{pH}$ (3.23) was recorded in freshly harvested tomatoes.

\section{DISCUSSION}

The results are in confirmation with the findings of Singh et al., (2000) who reported significantly maximum survival percentage of seedlings in onion after 80 days of transplanting with $60 \mathrm{~kg} \mathrm{ha}^{-1}$ phosphorus. As phosphorus stimulates blooming and 
fruit setting, therefore minimum days to $50 \%$ flowering (29.84) were recorded in plot of tomato plants fertilized with the dose of $60 \mathrm{~kg} \mathrm{ha}^{-1}$ phosphorus (Khan et al., 2000). Phosphorus as a component of nucleic acid helps in the production of large number of blossoms in the early growth of tomatoes (Melendez, 2012). Phosphorus played a positive role in fruit setting and helped in producing vigorous root and shoot system (Melendez, 2012). Fruit set is a key factor for yield. The early fruiting might be due to the healthy shoot system that gave early fruit set and eventually early fruiting. Sainju et al. (2003) also reported that phosphorus promoted early fruit set. As phosphorus enhanced development of reproductive parts stimulated blooming and fruit setting, therefore minimum days to fruiting were recorded in plot fertilized with lowest dose of $\mathrm{N}$ combined with phosphorus (Khan et al., 2000). Phosphorus played a vital role in early maturity of the tomato fruit, might be due to the reason that phosphorus helped in early flowering which in turn help in early fruiting. The minimum days to bulb maturity and minimum pre mature bolting percentage were noticed under $75 \mathrm{~kg}$ ha-1 phosphorus while, maximum days to bulb maturity and maximum pre mature bolting percentage were noticed under control (Singh et al., 2000). The present results are in accordance with the findings of Melendez (2012) that phosphorus helped in early flowering and fruiting. Zhu et al. (2017) reported that phosphorus application to tomato plants showed increase in number of pickings plot- 1 . The obtained findings are in agreement with the results of Dabire et al. (2016) who described that phosphorus applied to tomato plants showed more no of fruits plot-1 and no of pickings plot $^{-1}$. The increased in fruit weight might be due to enhanced food accumulation in edible parts (Omidbaigi et al., 2004). Zekri and Obreza (2002) stated that the process of photosynthesis of the plant dropped severely that resulted in smaller fruit when provided with low concentrations of NPK therefore, the growth of plant was stunted and reduced fruits were formed. Zhu et al. (2017) revealed that with the application of higher rates of NP fertilizers, maximum average tomato fruit weight can be achieved. In contradiction, Majanbu et al. (1985) found no response due to phosphorus fertilization to pod weight of okra. Phosphorus played an important role against disease incidence. It might be due to phosphorus supported in early phase of crop development, synchronized the germination process and led to enhanced final yield (Wang and Li, 2007). Shaheen et al. (2007) also described that phosphorus increased plant resistance against diseases. Asgedom and Becker (2001) also examined that plants applied with $60 \mathrm{~kg}$ ha-1 phosphorus showed least disease incidence $(6.87 \%)$ in tomato fruits as compared to $(20.89 \%)$ to those not treated with phosphorus. Similar results were reported by Saeed et al. (2015) who reported that plant height was significantly affected by different levels of phosphorus. Similar results were found by (Alabi, 2006) who stated that phosphorus level $125 \mathrm{~kg} \mathrm{ha}{ }^{-1}$ significantly increased pepper plant height up to $16.63 \mathrm{~cm}$. Phosphorus helped in developing vigorous root system that caused better utilization of water and other nutrients in the soil which resulted in strong growth of stem and healthy foliage (Abd-Alla et al., 1996). The results are in agreement with that of Baqa $e t$ al. (2015) who reported that in fenugreek plants, maximum no of branches was recorded when applied with FYM at 15 tons $\mathrm{ha}^{-1}$ and phosphorus rate of $60 \mathrm{~kg}$ $\mathrm{ha}^{-1}$ but the results were in contrast with Majanbu et al. (1985) who reported that branch production was not influenced by phosphorus. However, the present findings are in confirmation with that found by Alabi (2006) that no of branches plant ${ }^{-1}$ increases by applying $60 \mathrm{~kg} \mathrm{ha}^{-1}$ phosphorus. The minimum yield (9.90 ton ha1) was observed in control treatment. Conversa et al. (2013) reported that higher yield of tomato was obtained at higher phosphorus level, with an increase about $31 \%$ compared to control. The higher $\mathrm{P}$ rate significantly increased total and commercial yields compared to low $P$ rate. In addition, the higher $P$ rate sharply decreased non-commercial yield regardless of the $\mathrm{N}$ level (Zekri and Obreza, 2013). Similar results on the effect of P in increased eggplant fruit yield were also reported by Zipelevish et al. (2000). Ali (2004) studied that the firmness of tomato fruit decreased in storage. The results of present study also conformed the results Zekri and Obreza (2002) who observed that with the application of phosphorus, the fruit firmness of tomato fruit was not retained. The results also in accordance with Arthey and Ashurst (2005) who suggested that due to minimum variation in the structure of cell wall that breaks into simple sugars showed high stability of total soluble solids in fruits. The possible reason for this is that in most climacteric fruit carbon might be stored largely in the form of starch that become sweetened in storage conditions because it depend upon storage temperature (Beaudry et al., 1989). (Zekri and Obreza, 2002) observed that the fruits of plant contain high soluble solids content when grown at high rates of nitrogen or at low rates of phosphorus. Phosphorus retained the ascorbic acid content of tomato fruit during storage. It might be due to decreased in total soluble solids and high acidity in tomato fruit by application of phosphorus. The ascorbic acid of fruit gradually reduced with the maturation of fruit (Lazan et al., 1990; Selvaraj et al., 1982). Ascorbic acid content of field grown tomatoes increased to a maximum level when the fruits turned almost red (Di Matteo et al., 2010). Qualitative traits can be effected by the storage duration (Getinet $e t$ 
al., 2011). The increase in the $\mathrm{pH}$ of tomato fruit juice in storage conditions was also suggested by Faasema $e t$ al. (2011). Ameyapoh et al. (2008) attributed that decrease in ascorbic acid content was associated to the lowering of the pH. Omidbaigi et al. (2004) and Zekri and Obreza, (2013) explained that acidity of fruit juice increased when phosphorus applied in low amount due to which $\mathrm{pH}$ of fruit juice decreased.

\section{ACKNOWLEDGEMENT}

All authors are declaring no conflict of interest. The funds were not taken from any Government or NonGovernment Agency. We like to say thank you to Ms. Cui Lina from Daqing Foreign Language School for her valuable suggestions for the improvement of manuscript.

\section{REFERENCES}

Abd-Alla, A.M., S.M. Adam, A.F. Abou-Hadid, and I.S.S. Benjamien, 1996. Temperature and fertilizer effects on tomato productivity. Acta Hortic. 113-120.

Alabi, D.A., 2006. Effects of fertilizer phosphorus and poultry droppings treatments on growth and nutrient components of pepper (Capsicum Annuum L). African J. Biotechnol. 5:671-677.

Ameyapoh, Y., C. de Souza, and A.S. Traore, 2008. Hygienic quality of traditional processing and stability of tomato (Lycopersicon Esculentum) Puree in Togo. Bioresour. Technol. 99:5798-5803.

Arthey, D. and P.R. Ashurst, 2005. Fruit processing nutrition, products, and quality management. Second edition. Springer. https://www.amazon.com/Fruit-ProcessingNutrition-Products-Management/dp/0834217333.

Asgedom, H. and M. Becker, 2001. Effect of seed priming with nutrient solutions on germination, seedling growth and weed competitiveness of cereals in Eritrea. Deutscher Tropentag, Univ. Bonn and ATSAF. Margraf Publishers Press, Weickersheim, p. 282.

Baqa, S., A.Z. Khan, A. Ali, S. Anwar, B. Iqbal, and S. Khan, 2015. Influence of farm yard manure and phosphorus application on yield and yield components of wheat. Pure Appl. Biol. 4:458-464.

Beaudry, R.M., R.F. Severson, C.C. Black, and S.J. Kays, 1989. Banana ripening: Implications of changes in glycolytic intermediate concentrations, glycolytic and gluconeogenic carbon flux, and fructose 2,6-Bisphosphate concentration. Plant Physiol. 91:1436-1444.

Chapagain, B.P. and Z. Wiesman, 2004. Effect of potassium magnesium chloride in the fertigation solution as partial source of potassium on growth, yield and quality of greenhouse tomato. Sci. Hortic. (Amsterdam). 99:279288.

Conversa, G., C. Lazzizera, A. Bonasia, and A. Elia, 2013. Yield and phosphorus uptake of a processing tomato crop rown at different phosphorus levels in a calcareous soil as affected by Mycorrhizal inoculation under field conditions. Biol. Fertil. Soils 49:691-703.
Corbo, M.R., C. Altieri, D. D'Amato, D. Campaniello, M.A. Del Nobile, and M. Sinigaglia, 2004. Effect of temperature on shelf life and microbial population of lightly processed cactus pear fruit. Postharvest Biol. Technol. 31:93-104.

Dabire, C., A. Sereme, C. Parkouda, M.K. Somda, and A.S. Traore, 2016. Influence of organic and mineral fertilizers on chemical and biochemical compounds content in tomato (Solanum lycopersicum) Var. Mongal F1. J. Exp. Biol. Agric. Sci. 4:631-636.

Faasema, J., J.O. Abu, and J.S. Alakali, 2011. Effect of packaging and storage condition on the quality of sweet orange ( Citrus cinesis ). J. Agric. Technol. 7:797-804.

Firoz, Z.A., 2009. Impact of nitrogen and phosphorus on the growth and yield of okra [Abelmoschus esculentus (L.) Moench] in hill slope condition. Bangladesh J. Agril. Res. 34:713-722.

Getinet, H., T.S. Workneh, and K. Woldetsadik, 2011. Effect of maturity stages, variety and storage environment on sugar content of tomato stored in multiple pads evaporative Cooler. African J. Biotechnol. 10:1848118492.

De Groot, C.C., L.F.M. Marcelis, R. Van Den Boogaard, and H. Lambers, 2001. Growth and dry-mass partitioning in tomato as affected by phosphorus nutrition and light. Plant, Cell Environ. 24:1309-1317.

Khan, H., M. Khan, K. Rasul, A. Majeed, and F.A. Safi, 2000. Effect of different levels of nitrogen alone and in combination with constant doses of phospohorus and potassium on grwoth and yield of okra ( Abelmoschus esculentus L.) T-13 under the agro-climatic conditions of Mingora, Swat. Pakistan J. Biol. Sci. 3:2101-2104.

Khokhar, K., 2013. Present status and prospects of tomatoes in Pakistan. Agric. Corner. http://www.agricorner.com/present-status-and-prospectsof-tomatoes-in-pakistan/. Accessed 15 Aug 2018.

Kimura, S. and N. Sinha, 2008. Tomato (Solanum lycopersicum): a model fruit-bearing crop. Cold Spring Harb. Protoc. 3:1-10.

Lazan, H., Z.M. Ali, and W.C. Sim, 1990. Retardation of ripening and development of water stress in papaya fruit seal-packaged with polyethylene film. Acta Hortic. 269:345-358.

Majanbu, I.S., V.B. Ogunlela, M.K. Ahmed, and J.D. Olarewaju, 1985. Response of two okra (Abelmoschus esculentus L. Moench ) varieties to fertilizers : Yield and yield components as influenced by nitrogen and phosphorus application. Fertil. Res. 7:257-267.

Di Matteo, A., A. Sacco, M. Anacleria, M. Pezzotti, M. Delledonne, A. Ferrarini, L. Frusciante, and A. Barone, 2010. The ascorbic acid content of tomato fruits is associated with the expression of genes involved in pectin degradation. BMC Plant Biol. 10:163.

Melendez, M., 2012. Soil considerations for garden tomato production. Rutgers Coop. Ext. Mercer Cty. http://njfarmfresh.rutgers.edu/documents/SoilConsideratio nsforGardenTomatoProduction.pdf. 
Omidbaigi, R., F. Sefidkon, and F. Kazemi, 2004. Influence of drying methods on the essential oil content and composition of roman chamomile. Flavour Fragr. J. 19:196-198.

Saeed, K.S., S.A. Ahmed, I.A. Hassan, and N.J. Qader, 2015. Comparison of different levels of phosphate and biofertilizer of growth and yield on tomato (Lycopersicum esculentum Mill ) in green house condition. Am. J. Agric. Environ. Sci 15:210-215.

Sainju, U.M., R. Dris, and B. Singh, 2003. Mineral nutrition of tomato. Food, Agric. Environ. 1:176-184.

Selvaraj, Y., D.K. Pal, M.D. Subramaniam, and C.P.A. Iyer, 1982. Changes in chemical composition of four cultivars of papaya during growth and development. J. Hortic. Sci. 57:135-143.

Shaheen, A.., M.M. Abdel-Mouty, H.A. Aisha, and F.A. Rizk, 2007. Onion plant growth, bulbs yield and its physical and chemical properties as affected by organic and natural fertilization. Res. J. Agric. Biol. Sci. 3:380-388.

Singh, J., A. Kumar, and C. Singh, 2000. Influence of phosphorus on growth and yiel of onion (Allium cepa L.). Indian J. Agric. Res. 34:51-54.

Thumula, P., 2006. Studies on storage behavior of tomatoes coated with chitosan-lysozyme films. Faculty of Agricultural and Environmental Sciences.

Venema, J.H., B.E. Dijk, J.M. Bax, P.R. van Hasselt, and J.T.M. Elzenga, 2008. Grafting tomato (Solanum lycopersicum) onto the rootstock of a high-altitude accession of Solanum habrochaites improves suboptimaltemperature tolerance. Environ. Exp. Bot. 63:359-367.

Wang, Z. and S. Li, 2007. Effects of nitrogen and phosphorus fertilization on plant growth and nitrate accumulation in vegetables. J. Plant Nutr. 27:539-556.

Zekri, M. and T.A. Obreza, 2002. Plant nutrients for citrus trees. Univ. Florida - IFAS Ext. 200:1-5.

Zekri, M. and T. Obreza, 2013. Potassium ( k ) for citrus trees. Univ. Florida - IFAS Ext. SL381:1-4.

Zhu, Q., M. Ozores-Hampton, Y. Li, K. Morgan, G. Liu, and R.S. Mylavarapu, 2017. Responses of tomato to potassium rates in a calcareous Soil. HortSci. 52:764-769.

Zipelevish, E., A. Grinberge, S. Amar, Y. Gilbo, and U. Kafkafi, 2000. Eggplant dry matter composition fruit yield and quality as affected by phosphate and total salinity caused by potassium fertilizers in the irrigation solution. $J$. Plant Nutr. 23:431-442. 